\title{
Toonytools in Teaching Narrative Text: Pre Service Teachers' Experience
}

\author{
Dinda Nur Hanifah Septiyani, hanifahdin@gmail.com, English Language Education \\ Department, Tarbiyah and Teacher Training Faculty, Universitas Islam Negeri Sunan \\ Ampel Surabaya, Indonesia
Rizka Safriyani, rizkasafriyani@uinsby.ac.id, English Language Education Department, Tarbiyah and Teacher Training Faculty, Universitas Islam Negeri Sunan Ampel Surabaya, Indonesia

\author{
Siti Asmiyah, siti.asmiyah@uinsby.ac.id, English Language Education Department, \\ Tarbiyah and Teacher Training Faculty, Universitas Islam Negeri Sunan Ampel \\ Surabaya, Indonesia
}

\begin{abstract}
Technology has many applications in teaching and learning media. Learning media are needed to support the success of the teaching and learning process. Teachers must be creative in finding suitable media for classroom practice, and teaching media are required to keep the teaching and learning process successful. Comics are a media that provides fun content. Nowadays, people prefer to use comics online because they work a lot with online applications. Toonytools is one of the preferred online comic creators. This study aims to determine the use of Toonytools as a learning media in Narrative Text learning. This research was conducted using a mixed-method design to combine qualitative and quantitative methods to understand the topic. Twenty preservice teachers participated in both interviews and survey questionnaires. The finding indicated that the Toonytools online comic platform was constructive to make attractive learning media. This platform was easy to use and apply in classroom practices and supported by the finding, which increases students' learning motivation.
\end{abstract}

Keywords: Comics, Narrative, Media, Technology, Toonytools

\section{A. INTRODUCTION}

In the current Indonesian education curriculum, several English subject texts must be taught in writing at school. The type of text is a monologue text. Schools must master five genres. They are descriptive, procedural, reporting, recalculated, and narrative. However, many students still have difficulties writing narrative text, such as finding story ideas and finding main conflicts. There are several attempts by the teacher can do to make students interested and comfortable in learning narratives. One of them is by making media.

Media is one of the most widely used tools to help teachers bring material into the teaching and learning process to be more productive and efficient. Media is an essential means for students to make it easier for them to follow the material. Also, Chou et al. (2014); Ellis \& Highsmith (2000) state that most students can understand the material well as they are comfortable with the tools used in delivering the material, so the learning content will be easy to obtain. According to Guérin et al. (2017); Mina (2019), teachers are obliged to use or offer media to create something interesting in the learning system. It is hoped that the teacher can modify the media to make it creative and useful. Therefore, the development of the media from year to year will always change and develop.

The era that is currently being experienced is very advanced, where all needs can be easily obtained through technology. The right shot for the introduction of using technology is 
those who can compete in the digital age. Besides, Grootens-Wiegers et al. (2015); Megawati \& Anugerahwati, n.d. (2012); Sridhar \& Dragan (2017) show that online media is indispensable in forming an effective learning system and the introduction of technology in education. The scope that is often the target of introductory media is preservice teachers because they are expected to develop into professional teachers.

Several studies have discussed the influence of the right media in the classroom, both in quality, quantity, and media use attitudes. The results of several studies are Anida,

n.d. (2019); Gayathri, (2016); Uzun \& Kilis, (2019) revealed the relationship between media and student interest. Teaching materials using something as a tool to build learning motivation and relieve boredom significantly affects students; one of the things that support is interest in education. Other research from Inbarasan, n.d. (2016); Lauricella et al., (2020) provides stimulation to students. Make it easy to convey the material to be studied. Previous research was also conducted by Anuradha, (2016); Fajriyah, n.d. (2018); Paratore et al., (2016) discuss the relationship between media and material. The final result obtained is a high value when the teacher uses the media to explain the material compared to the teacher, who only explains the material without providing stimulus tools to stimulate students to respond to learning.

One of the main obstacles in using online media is its platform and how it is implemented. Therefore, this research leads to comic strips as the right strategy to help develop teaching skills in presenting attractive media to students. According to ÖzdemiR, (2017); Vinoliya, (2016) discuss a comic strip's physical form. The template uses at least one or more panels with the same or different views and usually a maximum of four panels. Several studies conducted previously by Anggraeni et al., (2015); Hands et al., (2018) stated that comic strips could facilitate students' understanding of learning materials through visual media. Comic strips as an educational tool can be used in various teaching and learning activities to increase learning motivation. Another study, according to Erixon, (2010); Honarvar \& Rahimi, (2011); Sarma, (2016) discussed the advantages of using comic strips that using comics makes learning more enjoyable and comfortable. They make it easier to convey the material because the comics' features are more attractive, such as selecting characters and colours supporting them.

A theory by Maulana (2017) has stated that the use of comics in language classrooms helps build vocabulary, reading, critical thinking, problem-solving, listening, speaking, and writing. According to Fatimah, (2018); Nisa \& Al-Hafizh, (2014), the comic strip has essential features. Panels that can be in the form of rectangles or circles that can be filled on one page. Next are various letters; word balloons; captions or dialogues; sound effects, such as laughter and crying; and multiple backgrounds according to the story that will be made like a forest or inside the house.

This phenomenon needs to be studied further. The material that can be raised and developed is narrative text material. Also, the curriculum, there is material about the narrative text as one of the teaching materials in the context of Indonesian ELT. Various narratives, such as myths, legends, fables, and fairy tales, can be displayed in one comic strip. Poai (2018) states that narrative can also be a form of teaching or information, even as a medium to channel someone's opinion about something. It is neatly packaged in a character story.

Extrinsic and intrinsic characteristics characterize an excellent narrative. The following is about external features by Efriza \& Radjab, (2013); Martages et al., (2017); the first is a series of meaningful and dramatic events that make up the story. Second, it includes information about when and where the events in the story took place. Third, ordering due to textual action is the sequence of events in time. Next is intrinsic; according to Muyassaroh et al., (2019); Zaim \& Hum, (2016), using words that indicate sequential time connectivity, verbs in the past tense, use of action verbs that show what is happening, there is descriptive language to describe someone. 
Several previous studies have provided answers to the effectiveness of using comic strips to improve student achievement and stimulate student motivation. It is because they are equipped with exciting pictures and chronological stories. The extensive study of comic strips in recent years mostly took data in junior and senior high schools (see Megawati \& Anugerahwati, n.d. (2012), and Rokhayani (2014)). Also, most of the previous researches were conducted by quantitative methods (see Poai, (2018), and Efriza \& Radjab, (2013); Martages et al., (2017)This study only used comic strips made by teachers, not using an online cartoon platform that everyone could use.

Previous research that discussed comic strips, Ravelo, (2013) stated that comic strips as a medium in learning narrative text could increase student motivation to learn English in narrative text. It can be seen from the significant increase in student scores. Further research previously by Apriani (2014) showed a significant difference between student achievement in understanding reading texts between students using comic strip media and students using serial images. The measurement results show that the reading comprehension line is higher using comic strips.

Through the results of various studies that both use comic strip media, this study will examine an online comic platform to provide a different product from previous research. The researcher decided to make comics using a website called Toonytools. It is a free website that allows those around us to develop comics quickly. This research could also help teachers find media platforms during the Covid-19 pandemic. Nowadays, teachers need a platform that is easy to use. This study investigates the use of Toonytools as a comic strip platform to teach narrative text as English teaching materials. This study also uses a qualitative approach where the data is taken from students who act as preservice teachers.

\section{B. METHOD}

A mixed-method methodology used an explanatory design to sequentially collect data using qualitative and quantitative approaches to solve research problems. However, though qualitative data were administered to refine the quantitative approach's findings based on a debriefing procedure with participants, the quantitative data were prioritized. There were twenty preservice teachers of UIN Sunan Ampel Surabaya who were involved as the research participants. In the research process, two datasets have been obtained, analyzed separately, and compared. By conducting a questionnaire and a semi-structured interview, the study was performed using a survey research design. A survey was done to describe the implementation of the Toonytools platform for teaching narrative text. Next, a semi-structured interview was used to elicit information about Toonytools. However, the interview guide was designed and validated by an expert before it was applied to the participants. One of these experts is a lecturer with a language education background. The researcher transcribed all interview data into word documents. The responses were coded deductively to determine the thematic analysis of the Toonytools implementation. Finally, the conclusion was drawn inductively.

\section{RESULT AND DISCUSSION}

Teaching on narrative text material using Toonytools as an online comic platform is very helpful for teachers. As they combine two types of cultural expression, namely literature and art, comics are also powerful teaching tools. The Toonytools platform consists of colourful pictures, exciting stories, and digital media, which are very important for students - equipped with a background that can be adapted to the story, various character choices, different conversation balloons, and other supporting forms. Another advantage of Toonytools is that users do not need to worry about large internet quotas because Toonytools is a platform that stores internet 
connections. The result of the questionnaires indicates that almost all preservice teachers have used comics online for learning media. Using their experience, nearly all respondents have made comics online with various platforms. However, $95 \%$ of respondents claimed interested in this platform.

Based on the interview, Toonytools can be used for storytelling activities. Preservice teachers introduce a topic and assign students to create 2 to 4 comic panels that discuss a predetermined problem or problem. Ask students to develop a coherent narrative storyline and encourage them to write dialogue that uses natural speech patterns. Teachers can ask them to draw their panels or use a platform they find online. The second activity can do retelling. After students have read a story, ask them to retell the main plot points of the information using a comic. They can draw or ask them to look for similar examples in the story. The third activity can be a continuation of the story. Give students 2 to 4 pre-designed comic panels, but leave the dialogue boxes blank. Then, ask students to fill in the blanks, making sure to tell a story based solely on the other visual elements of the strip. As an alternative, the teacher can also use comics that have been designed beforehand. Still, the last panel is not there, then ask students to complete the story using inference clues, predictions, and context. The fourth activity can be done by introducing the topic or guessing the information. Discuss new issues or problems using comic strips. The comic strip selected must reflect the main idea of the situation without actually expressing it. Ask students to brainstorm what they can conclude from the comic and perhaps try to predict what will happen next. The last one is carrying out awareness-raising activities. Comics are distinct from movies and cartoons that decide the rate of viewing. Comic time, meanwhile, progresses at the pace of the reader.

This study's findings show that teachers and students can enjoy Toonytools in making online comics. They claim to be more effective and efficient, coupled with the features of an easy-to-apply platform. Compared with previous studies, which only said the use of online comics with the help of Toonytools, the results were more transparent. No doubt, research on a comic platform with a bright name, namely Toonytools, had a good impact according to the data results obtained than with a study that only examined general usage comics.

Furthermore, they informed that $95 \%$ of the respondents had used comics as a learning medium to teach narrative. By using Toonytools, the learning objectives were well achieved. Moreover, the interview result indicates that using an online comic platform can foster teachers' self-confidence and creativity. This finding is in line with Rokhayani (2014), which states that comics as a media in learning narrative text can improve students' reading skills and motivate them to learn English. Comics are an art form that uses a series of static images in a fixed order. This study also obtained similar results to previous research. The respondents also felt motivated and interested in using comics through Toonytools because it could increase student creativity and motivate students to learn by using comics as teaching materials.

The other exciting findings refer to the preservice teachers' experience in knowing the Toonytools. The interview result shows that most of the preservice teachers have got information about Toonytools from their friends. There were $60 \%$ of the preservice teachers got the information from their friends. Furthermore, $10 \%$ of the preservice teachers get this information through personal browsing while looking for an online comic maker. There are about $30 \%$ of preservice teachers get information about Toonytools from their friends.

The survey results show that online comics are suitable for Junior High School level and Senior High Schools. There were $45 \%$ of the preservice teachers state that Toonytools is suitable for Junior High School level. Students tend to find it easier to grasp the material at the junior secondary level. Toonytools is also suitable for Senior High School students. Figure 1 indicates that Toonytools can help students develop their ability to create dialogue. In Senior 
High School levels, Students also learn about Narrative Text. However, the narrative text in Junior High School usually has a simple language. In Senior high Schools, the language used is more complex and expressive. Therefore, Toonytools could facilitate not only language development but also the idea of story development. It is possible to apply educational e-comics that emphasize character education and increase student motivation for learning to enhance student learning outcomes.

Figure. 1. The example of Narrative Text Fragment

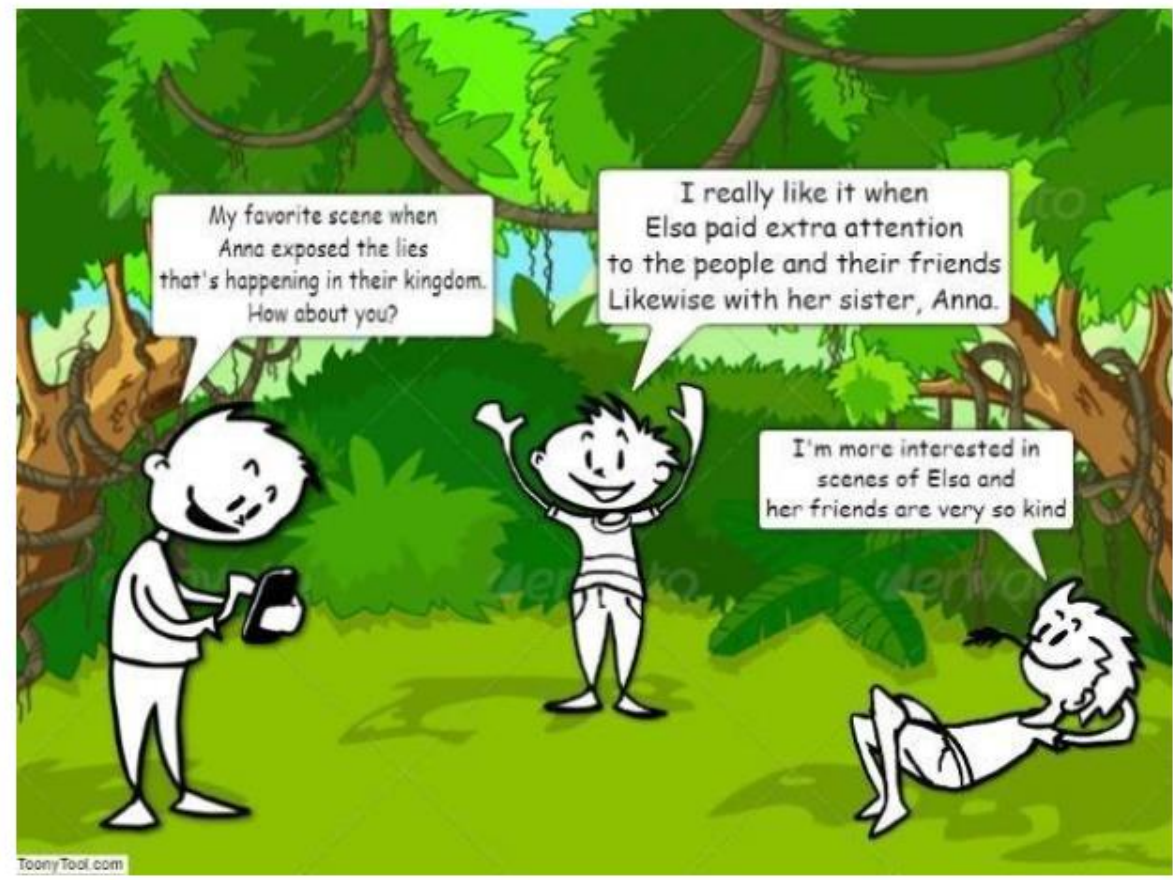

Further interview results reveal that the reason why many respondents chose Toonytools because it is user friendly. Moreover, Toonytools did not need a high-speed internet connection. It can work on a medium speed internet connection. A medium-speed internet connection is a reason why Toonytools is favorable. There were $60 \%$ of participants only took 15 minutes to create an online comic using Toonytools. $30 \%$ of participants need only 10 minutes to create one Narrative Text, and there were $10 \%$ of the participants spent 20 minutes to create one Narrative Text. There are some reasons why students need to read comics. Comics are known to enhance memory. Comics are created sequentially, requiring one's own memory and imagination. Comics present an unusual story in their introduction. Furthermore, comics are used as a way to study literature that is difficult and yet easy to understand in many ways. Comics can be used as character learning. Talking about the genre, most participants prefer to create fairy tales such as Cinderella, Frozen, and now White. The fable is also chosen for the comics. The stories of turtles, mouse deer, rabbits were created by using Toonytools. That is why comics are more suitable to be used or combined with narrative text types. In general, students feel comfortable integrating knowledge in the form of images and text in comics since comics have a certain appeal to school-age children. Comics typically provide various messages for students, such as unity, friendship, and integrity. These messages can be derived from fairy tales or fables. Furthermore, Students most frequently prefer comic book literature over conventional text because comics provide illustrations, pictures, and other art and words and dialogue. Comics can make it easier for readers to grasp the quality of reading. Besides, comics can generate written excitement because kids want to imagine. Comics can contribute to the comprehension of new words and can be used to broaden the imagination they own.

Furthermore, students enjoy comics because they can get to know personal and social issues by 
recognizing comics characters. By creating comics, students can solve their problems. The interview further shows that preservice teachers prefer this platform to others because Toonytools is more effective and efficient. Comics with their distinctive features have great power when discussed adequately in the classroom to tell a story and communicate messages, promoting active engagement and student imagination. However, It has been argued that there are some weaknesses. Most of the characters are black and white, and the background lacks contrast with the characters. However, Toonytools can be exciting media to motivate students to learn English.

Megawati \& Anugerahwati, n.d. (2012), indicate that student learning achievement has increased because of the comic strips. It means that learning to write a narrative using comic strips has increased significantly, especially in terms of grammar, vocabulary, and mechanics. The progress of content elements is influenced through clear and legible dialogue, supported by images that reflect activities and understanding questions during the discussion session and the results of this study. The score obtained is $95 \%$ of the respondents managed to get high scores in success during making comics because it can teach students how to understand a text. The results show that students can also apply text through comics. Comics can be used in many ways to express messages in different disciplines. This comic's style is also offered as a severe clarification of its entertainment-only aspect because of its appealing appearance. Comic media helps inspire learners to be able to arouse interest and motivation.

The previous study shows that comic strips are also more practical; moreover, the states using comic strips are the most influential media because they consist of pictures and storylines that make students more interested in reading. Students must understand the storyline and comics to make sublime text. Comics, in artistic ways, incorporate text and pictures. This mix is what makes it possible for people of all ages to appreciate comics. So it is a comic that can draw students' interest and excitement to learn and teach students to translate the story into photographs, even as if students are faced with a real context so that students have a lasting impact and can remember for longer. Comic content should be described frankly, which means that the material is in photographs that can illustrate the whole plot.

Teaching materials about a narrative text must be well prepared. Before using comics as a learning tool, the features of these comics must be carefully formulated in accordance with the needs of these students and the characteristics of these students. It can attract students' interest in learning to deliver educational messages through comic media. The respondents have to make lesson plans according to the actual conditions and situations in the classroom. Organizing the classroom and teaching and learning process seems to be a tricky matter for teachers. The teaching and learning process uses comic strips for students. Based on respondents' observations, it is easy to explain the material because it uses exciting media. The comic strips make students comfortable to understand and enjoyable to read the material.

The results of this study suggest that comic strips using the Toonytools platform can be an exciting medium. Comic fosters learners and can create interest in learning. Comics can help them improve language skills, artistic activities, and in-depth creative statements that tell stories, dramatization, reading, writing, painting, drawing, and helping them understand and recall the content of textbook reading material. It is also suitable for presenting narrative text in different ways because comics consist of a generic narrative text structure, namely orientation, complication, and resolution. The use of educational media would significantly contribute to the learning process's success and the distribution of content messages for learning. Besides generating interest, student comprehension can be strengthened by the media. The goal of comics production is to create a product in the form of a material economic system of economic comics and gain eligibility as a learning medium. 
Moreover, comic stories are considered as a communicative source for language exposure. Exposure affects students' way of thinking in understanding certain information during reading activities. This study revealed that most students could understand the story well and transfer the word to their written product. Besides, the use of comics makes students' attention full for the learning process. It affects their motivation and learning to write good English. If the class is fun and exciting, students will like it to learn more, preferably. The right strategy, combined with teaching media's attractiveness, is highly recommended to create the current conditions during a pandemic. Learning styles or techniques that are fun in the classroom can increase student motivation to learn.

Concerning the stages of the learning process, comic strips play an essential role in learning activities. Students are provided with topics in the form of stories to get ideas that will later be outlined in a narrative framework as an outline in developing a narrative composition. Reflecting on the fact that the pre-writing stage is the first step to encourage idea generation, the comic strategy in this study showed that it is very influential in helping students write appropriately in terms of content and organization. Educational comics are also beginning to attract attention among educators because they increase comprehension and interest, increase learning motivation, improve actions, increase productivity and creativity, decrease stress and anxiety, increase active student engagement in the learning process, and can decrease boredom

Vanderhaegen (2013) states that comics make students feel there are variations in the learning process. So, they do not get bored with learning English. The results are also revealed through data analysis. The comic strip using the Toonytools platform has many diverse illustrated characters and backgrounds added by themselves through uploads. So, the results of using comics through Toonytools can be considered in line with previous research that comics can be an exciting variation of learning. The comic strip was proved effective in teaching students' narrative text. On the other hand, comic strips are the most influential media because it consists of pictures and storylines that make students more interested. Moreover, this platform is handy and easy to use. The students have to understand the storyline and the comic strip to create a good text. Although participants reported the challenge about the use of Toonytools, they were aware that this problem could be solved mainly by their efforts; preparing some pictures before the session. However, they also recommended that the topic be provided before creating the comics to create the comic faster.

The lack of the participant's language and technology mastery was a significant limitation in this study. Choosing a similar language and technology level of preservice teachers should be considered to help verify any challenges in using Toonytools in Narrative Text. Future research needs to consider the effectiveness of Toonytools to teach the other genre text such as Descriptive text or Argumentative text.

\section{CONCLUSION}

Teachers need to master their talents, their ability to adapt to emerging technology, and their global challenges. The achievement of learning activities can be measured by the results of learners in understanding the learning content. Besides, the availability of learning facilities, such as teaching materials, is one factor that influences the success of learning. A significant element in learning is instructional materials. The lack of teaching materials will impact learning outcomes. Comic strips can be the media of choice in students learning about the narrative text. So, English teachers can use this platform to learn in the teaching and learning process. As we know before, media is a means of increasing student interest in learning narrative texts and other texts in general. Here the researcher suggests comic strip media because it can increase student interest and motivation. This research can be a reference for 
investigating the use of comics in students' narrative text learning. Make the learning process more exciting and fun by using this Toonytool media to teach narratives and create stories quickly. The use of pictures can help students understand the storyline easily and be involved in the learning process. Toonytool that is easy for teachers to make to encourage writing creativity in learning narrative text. The teacher's role in using comics to teach students also varies. Various activities can be moderated by using comic strips as the principal capital for learning.

\section{E. REFERENCES}

Anggraeni, R. G., Martono, M., \& Rais, A. D. (2015). Improving Students' Writing Skill by Using Comic Strips. English Education, 4(1), 1. Https://Doi.Org/10.20961/Eed.V4i1.34615

Anida, N. (2019). Department Of English Education Faculty of Tarbiya and Teachers Training State Islamic University Of North Sumatera. 95.

Anuradha, V. (2016). Elt, Efl, Comprise Enjoyment, Language Acquisition, Integrating Comics, Vocabulary Acquisition, Analytical Thinking In Grammar. 3.

Apriani, W., \& Vianty, M. (2015). The Use of English Comic Book Series In Teaching Reading Comprehension. 7.

Chou, H.-W., Chen, Y.-L., \& Chou, S.-B. (2014). A Method For Evaluating The Creativity of Comic Strips. Thinking Skills and Creativity, 14, 11-19. Https://Doi.Org/10.1016/J.Tsc.2014.06.005

Efriza, D., \& Radjab, D. (2013). The Effect Of Using Numbered Heads Together And Reading Motivation On Students' Reading Comprehension Of Descriptive And Narrative Text Of Smpn 7 Muaro Jambi. 1, 10.

Ellis, A., \& Highsmith, D. (2000). About Face: Comic Books In Library Literature. Serials Review, 26(2), 21-43. Https://Doi.Org/10.1080/00987913.2000.10764580

Erixon, P.-O. (2010). School Subject Paradigms And Teaching Practice In Lower Secondary Swedish Schools Influenced By ICT And Media. Computers \& Education, 54(4), 1212-1221. Https://Doi.Org/10.1016/J.Compedu.2009.11.007

Fajriyah, N. (2018). English Education Departement Teacher Training and Education Faculty State Institute for Islamic Studies (Iain) Of Salatiga. 113.

Fatimah, S. (2018). Teaching Writing Narrative Text by Using Webtoon Digital Comic to Senior High School Students. 7(4), 7.

Gayathri, V. (2016). Comics, Jataka Tales, Moral Values, Buddhist Idealism, Modern Times.

3.

Grootens-Wiegers, P., De Vries, M. C., Van Beusekom, M. M., Van Dijck, L., \& Van Den Broek, J. M. (2015). Comic Strips Help Children Understand Medical Research. Patient Education and Counseling, 98(4), 518-524. Https://Doi.Org/10.1016/J.Pec.2014.12.005

Guérin, C., Rigaud, C., Bertet, K., \& Revel, A. (2017). An Ontology-Based Framework for the Automated Analysis and Interpretation of Comic Books' Images. Information Sciences, 378, 109-130. Https://Doi.Org/10.1016/J.Ins.2016.10.032

Hands, T., Shaw, A., Gibson, M., \& Miller, K. (2018). People and Their Plants: The 
Effect of an Educational Comic on Gardening Intentions. Urban Forestry \& Urban Greening, 30, 132- 137. Https://Doi.Org/10.1016/J.Ufug.2018.01.017

Honarvar, H., \& Rahimi, A. (2011). Surveying Techniques for Cultural Problems of Children Comic Strips Translation. Procedia - Social and Behavioral Sciences, 28, 1076-1078. Https://Doi.Org/10.1016/J.Sbspro.2011.11.194

Inbarasan, V. (2016). Effectiveness of Using Comics in Teaching Phrasal Verbs To Tertiary Level Students. 1.

Lauricella, A. R., Herdzina, J., \& Robb, M. (2020). Early Childhood Educators' Teaching of Digital Citizenship Competencies. Computers \& Education, 158, 103989. Https://Doi.Org/10.1016/J.Compedu.2020.103989

Lavin, M. R. (1998). Magazines And Journals About Comic Books. 12.

Martages, I. F., Suharjito, B., \& Santihastuti, A. (2017). The Effect Of Using Comic Strips On The Eighth Grade Students' Narative Writing Achievement At Smp Negeri 5 Jember. Jurnal Edukasi, 4(2), 1. Https://Doi.Org/10.19184/Jukasi.V4i2.5201

Maulana, Y. (2017). Teaching Reading By Using Comic Strips To Improve Junior High School Students' Comprehension. 6(1), 8.

Megawati, F., \& Anugerahwati, M. (2012). Comic Strips:A Study OnThe Teaching Of Writing Narrative Texts To Indonesian Efl Students. 23.

Mina, L. W. (2019). Analyzing And Theorizing Writing Teachers' Approaches To Using New Media Technologies. Computers and Composition, 52, 1-16. Https://Doi.Org/10.1016/J.Compcom.2019.01.002

Muyassaroh, M. N., Asib, A., \& Marmanto, S. (2019). The Teacher's Beliefs and Practices on The Use of Digital Comics in Teaching Writing: A Qualitative Case Study. International Journal of Language Teaching and Education, 3(1), 45-60. Https://Doi.Org/10.22437/Ijolte.V3i1.6502

Nisa, F., \& Al-Hafizh, M. (2014). Teaching Writing a Narrative Text by Using Comic Creator (Bitstrips) As a Medium To Second Grade Students Of Junior High School. 3(1), 6.

Özdemir, E. (2017). Humor in Elementary Science: Development and Evaluation of Comic Strips about Sound. 4, 14.

Paratore, J. R., O'brien, L. M., Jiménez, L., Salinas, A., \& Ly, C. (2016). Engaging Preservice Teachers in Integrated Study and Use of Educational Media and Technology in Teaching Reading. Teaching and Teacher Education, 59, 247-260. Https://Doi.Org/10.1016/J.Tate.2016.06.003

Poai, S. T. (2018). Teaching English Vocabulary Using Comic Strips. 4(1), 8.

Ravelo, L. C. (2013). The Use of Comic Strips as a Means of Teaching History In The Efl Class: Proposal Of Activities Based On Two Historical Comic Strips Adhering To The Principles Of Clil. Latin American Journal of Content and Language Integrated Learning, 6(1), 1-19. Https://Doi.Org/10.5294/Laclil.2013.6.1.1

Rokhayani, A., \& Utari, A. R. P. (2014). The Use of Comic Strips as an English Teaching Media For Junior High School Students. 7.

Sarma, L. S. (2016). Teaching English through Comics. 2.

Sridhar, A., \& Dragan, A. (2017). Comic for Contraceptive Implant Information: A PrePost Test Quasi-Experimental Study. Contraception, 96(4), 279-280. 
Https://Doi.Org/10.1016/J.Contraception.2017.07.068

Uzun, A. M., \& Kilis, S. (2019). Does Persistent Involvement In Media And Technology Lead To Lower Academic Performance? Evaluating Media And Technology Use In Relation To Multitasking, Self-Regulation And Academic Performance. Computers in Human Behavior, 90, 196-203. Https://Doi.Org/10.1016/J.Chb.2018.08.045

Vanderhaegen, F. (2013). Toward A Reverse Comic Strip Based Approach To Analyse Human Knowledge. Ifac Proceedings Volumes, 46(15), 304-309. Https://Doi.Org/10.3182/20130811- 5-Us-2037.00051

Vinoliya, D. A. (2016). Implementing Comic in Elt In Primary Schools. 3.

Zaim, D. M., \& Hum, M. (2016). The Power Of Multimedia To Enhance Learners' Language Skillsin Multilingual Class. 8. 